\title{
Protecting Sydney's Peri-Urban Agriculture: Moving beyond a Housing/Farming Dichotomy
}

\author{
SARAH W. JAMES \\ Department of Environment and Geography, Macquarie University, Balaclava Road, North Ryde, \\ NSW 2109, Australia. Email: sarah.james@mq.edu.au
}

Received 12 May 2013; Revised 11 October 2013; Accepted 14 October 2013

\begin{abstract}
In Australia, as in other Western countries, peri-urban farmland is increasingly being considered a public good, contributing to urban sustainability and climate change mitigation. To retain local food production, advocates have called for the implementation of farmland protection policies that restrict urban development, such as exclusion zoning. Many such policies have been abandoned due to protests, often from the very people the policies are ostensibly intended to protect - farmers. Examining the failure of Sydney's latest 'green zones' through a political ecology lens, this paper challenges the prevailing narrative that these protests indicate a lack of community support for the ideal of farmland protection. The failure of the green zones was one of political process, specifically the lack of consultation with Sydney's culturally and linguistically diverse small-scale farmers, rather than community rejection of the principle of protection. Interview responses from farmers suggest that a bottom-up approach to policy-making would have yielded alternative and more successful approaches to maintaining farming on the fringe. This paper concludes that ensuring small-scale farmers have access to and agency in the environmental decision-making process generates options for farmland protection policy that move beyond a housing-versusfarming dichotomy.
\end{abstract}

KEY WORDS urban agriculture; urban planning; Sydney; urban political ecology

\section{Introduction}

Echoing trends in countries such as the UK and the USA, Australian peri-urban agriculture has gained increased public attention and support in recent years. Advocates across industry, government and academia argue that localised food production represents a 'common good', contributing to urban sustainability and climate change mitigation. Despite recognition of the importance of urban agriculture in planning rhetoric, however, public support has not translated into the implementation of substantive farmland protection policies in Australian cities. In Sydney, Australia's largest city, the latest plan for farm- land protection through the creation of green zones on the urban fringe was abandoned before it was implemented due to community protest. The official conclusion of government representatives was that these protests against green zones represented a public rejection of farmland protection. The protests were seen to be in support of a prevailing housing/farming dichotomy that had informed Sydney planning for many decades. That even farmers, so it appeared, did not want protection was interpreted as a justification of a continued prioritisation of housing and lack of action on farmland protection by the state government planning 
department. This paper adopts an urban political ecology perspective to challenge this narrative, and as I go on to elucidate, argues instead that the protests represented a lack of equity in the policy-making process.

Urban political ecology seeks to interrogate narratives that naturalise negative environmental outcomes, drawing attention instead to the instrumental role politics often plays in such outcomes. Key to unpacking the power struggles behind environmental initiatives is examining who had access to and agency in the decision-making process, as this has significant impact on who pays for and who gains from the final policy (Swyngedouw and Heynen, 2003). In the case of Sydney's green zones, it would appear that only some of the varied stakeholders in the fringe farmers, large landowners, small residential owners, housing developers, and city dwellers were considered to represent the 'community'. This was pivotal in determining whose voices were heard in the consultation process and, subsequently, whose interests were served by the final policy. Interviews with 28 culturally diverse small-scale farmers from Sydney's fringe revealed that, critically, they were not adequately consulted in the policy development process. They felt they were left with all the costs of farmland protection, but no say in how it was implemented. Farmers had a number of alternative approaches to farmland protection that moved beyond a housing-versus-farming dichotomy and could have been adopted had more inclusive consultation occurred. These findings challenge the perceived inevitability of peri-urban farmland loss. The failure of the green zones is exposed as the outcome of a particular policy-making process rather than a community rejection of a sustainability ideal or an essential incompatibility of housing and farming. This paper concludes that a more bottom-up approach to policy-making offers the possibility for a greater policy success in the future.

\section{Farming versus housing? Sydney's history of (failed) farmland preservation}

In recent decades, little attention has been given to those areas at the edges of cities in Australian urban policy or planning scholarship except as a site for future housing development (Bunker and Houston, 2003). With the focus on the inner city as the engine for economic growth and cultural dynamism (McNeill et al., 2005), the peri-urban edge has continued to be seen as a transitional zone that will move further out as urbanisation continues to spread, or as many city-centric commentators dismissively call it, 'sprawl' (Anderson, 2005). Peri-urban agriculture has largely been considered a transient land use by policy makers, overlooked and undercounted due to a focus on broad-acre agriculture as the primary site of food production (James et al., 2010).

Despite its neglect in planning policy and scholarship, peri-urban agriculture has received increasing attention in Australian public discourse since the early 2000 s due to rising concerns about the effects of climate change and population health (Dixon et al., 2007; Land and Water Australia, 2008). Local agriculture is constructed by its advocates as a public good that can positively contribute to these concerns; it is seen to decrease the environmental effects of longhaul food transport, provide better-quality food to the city population and protect agricultural soils, as well as provide additional amenity and heritage value to urban areas (Mougeot, 2005). Those advocating for the protection of local agriculture in Australian cities are drawn from a range of sectors, including academics, government, health and agriculture, as well as the general public.

The continued urban expansion of Australian cities, however, particularly on the fertile east coast, is posing a significant threat to the agricultural industries that exist in the peri-urban landscapes that radiate out over $100 \mathrm{~km}$ from the city (Low Choy et al., 2008). In Sydney the threat posed by planned housing growth on the urban fringe has been quantified in stark terms. A report for Horticulture Australia Limited and the New South Wales Department of Primary Industries indicated that the areas designated as 'Growth Centres' for housing on the urban fringe also contained approximately 52 per cent of properties growing vegetables in the Sydney Basin (Malcolm and Fahd, 2009). This statistic suggests that unless measures are undertaken to address it, Sydney's vegetable industry would be significantly damaged by the planned growth. With peri-urban zones expanding around Australia's major cities creating a direct threat to fringe farmland, there is a clear need for direct planning measures if this perceived common good is to be protected. The challenge for planners, however, remains how to balance the protection of farmland with the pressure for housing growth.

On the limited occasions they have been implemented, policies for the protection of periurban farmland around Australian cities have 
largely followed the green-belt model exported from England (Freestone, 1992). This model focuses on broad countryside preservation rather than specifically agricultural land, based on the assumption that limiting development will protect agriculture (Ali, 2008). While intended to solve the problem of urban sprawl, internationally, green belts have historically exacerbated conflicts over the need for space for housing and urban expansion (Amati, 2008). The result of protests by landowner and developer groups has often been that farmland is eventually lost to housing. Drawing comparisons between the failure of the original 1951 Sydney green belt and the 2005 green zones, this paper interrogates the prevailing government assumption that these protests indicate that not only is the loss of fringe farms an inevitable outcome of urban growth, but that the public do not even want them protected. Instead it argues that in both instances a topdown approach to policy making meant political power struggles were as much to blame for these failures as ostensibly incompatible land uses.

The first and most well-known attempt to protect Sydney's peri-urban lands through restrictions on development was the 1951 creation of a 'green belt' that would encompass the entire city. At the time Denis Winston, Professor of Town and Country Planning at the University of Sydney, emphasised the importance of the green belt for urban sustainability:

Australia has nearly three million square miles of territory but really good growing land with adequate rainfall makes up a very small percentage of the total: where such favourable land occurs near a large population centre it is of double importance, for only from such areas can really fresh vegetables come to city markets. ... The first essential [task for planners] is to preserve the land where they can be grown: to raise bungalows on first-class agricultural land may be profitable for the 'developers' but is a serious loss for everyone else. (Winston, 1957, 7-8)

The green belt was part of the first metropolitan scale plan for Sydney after World War II, the County of Cumberland Plan of 1951. A green belt around the city was designed to create a natural boundary to what was considered 'promiscuous suburbanisation' and to ensure that city dwellers had access to green environs close to home (Spearritt and Demarco, 1988, 23). Despite the importance advocates such as Winston attributed to it, the 1951 Sydney green belt was eventually abandoned as development slowly ate away at the reserves of greenfield land until it was destroyed (Spearritt and Demarco, 1988).

The failure of the green belt was construed as the inevitable loss of rural land to the pressure for housing development in a growing city. The prevailing view that protection of Sydney's periurban rural land, including farmland, had been tried and failed meant that it virtually disappeared as an urban planning issue in subsequent metropolitan scale plans for Sydney. Instead the fringe was marked as a site for future housing growth, with a discourse of a 'lack of space' for anything other than housing mobilised by both government and development interests to support further greenfield expansion. The statement in the 1967 metropolitan plan that 'land remaining for residential development in the zoned urban areas of Sydney will have been exhausted within a few years' time' exemplifies this prioritization of housing growth on the fringe after 1951 (State Planning Authority of New South Wales, 1967, 10).

A more detailed analysis of the failure of the green belt, however, highlights the role of politics, particularly the lack of on-ground consultation with landholders, in its collapse. According to Freestone (1992), the green belt was designed and implemented in a top-down manner by the state government planning authority. Many local councils and landowners felt they had not been sufficiently consulted in the creation of the green belt. This was a key factor in the eventual abandonment of the green belt, as numerous developments were approved at the level of local government that destroyed the green belt incrementally (Freestone, 1992).

More than 60 years on from the original green belt, Sydney's 2005 Metropolitan Strategy, 'City of Cities', initially appeared to offer a better balance between farming and housing than any plan since 1951. It indicated an official acknowledgement of the contribution of agricultural lands to the city and the need to limit urban growth to protect them:

Rural and resource lands constrain expansion of the urban areas and reinforce a compact city where infrastructure and services can be sequenced and efficiently developed. They provide fresh local produce, reducing the need to transport food long distances and complement Sydney as a sustainable food capital. (New South Wales Department of Planning, 2005b, 205) 
Housing development on the fringe, however, continued to be a key part of this vision of urban growth. The 2010 review of the 2005 Metropolitan Strategy estimated that the city's population would increase by 1.7 million, reaching 6 million people by 2036 (New South Wales Department of Planning, 2010). In the 2005 Metropolitan Strategy, the majority of new greenfield development was in two Growth Centres in the northwest and south-west of Sydney, where the majority of Sydney's vegetable farms were located (see Figure 1).

To balance these goals of protecting rural land uses and facilitating housing development, the Metropolitan Strategy instituted 'Rural and Lifestyle Zones', known colloquially as green zones, in the two new Growth Centres (New South Wales Department of Planning 2005a). The intention was that there would be large tracts of 'rural' land throughout the Growth Centres, ensuring that rural lifestyles (including farming) could continue and providing additional benefits such as visual amenity for the new residents and protecting remnant areas of woodland and waterways. In the original plans, these green zones were to remain under their current zoning, which was generally rural-residential (New South Wales Department of Planning, 2005a). As a result, landowners in the green zones would be able to continue existing land uses such as farming but, critically, could not sell their properties for housing development.

Rather than applauding the attempt by planners to strike a balance between development and conservation, many residents (predominantly homeowners, not farmers) in the proposed Growth Centres protested strongly against these plans. Approximately 3000 letters were written in response to the planned green zones (Growth Centres representative 2, pers. comm., 25 June
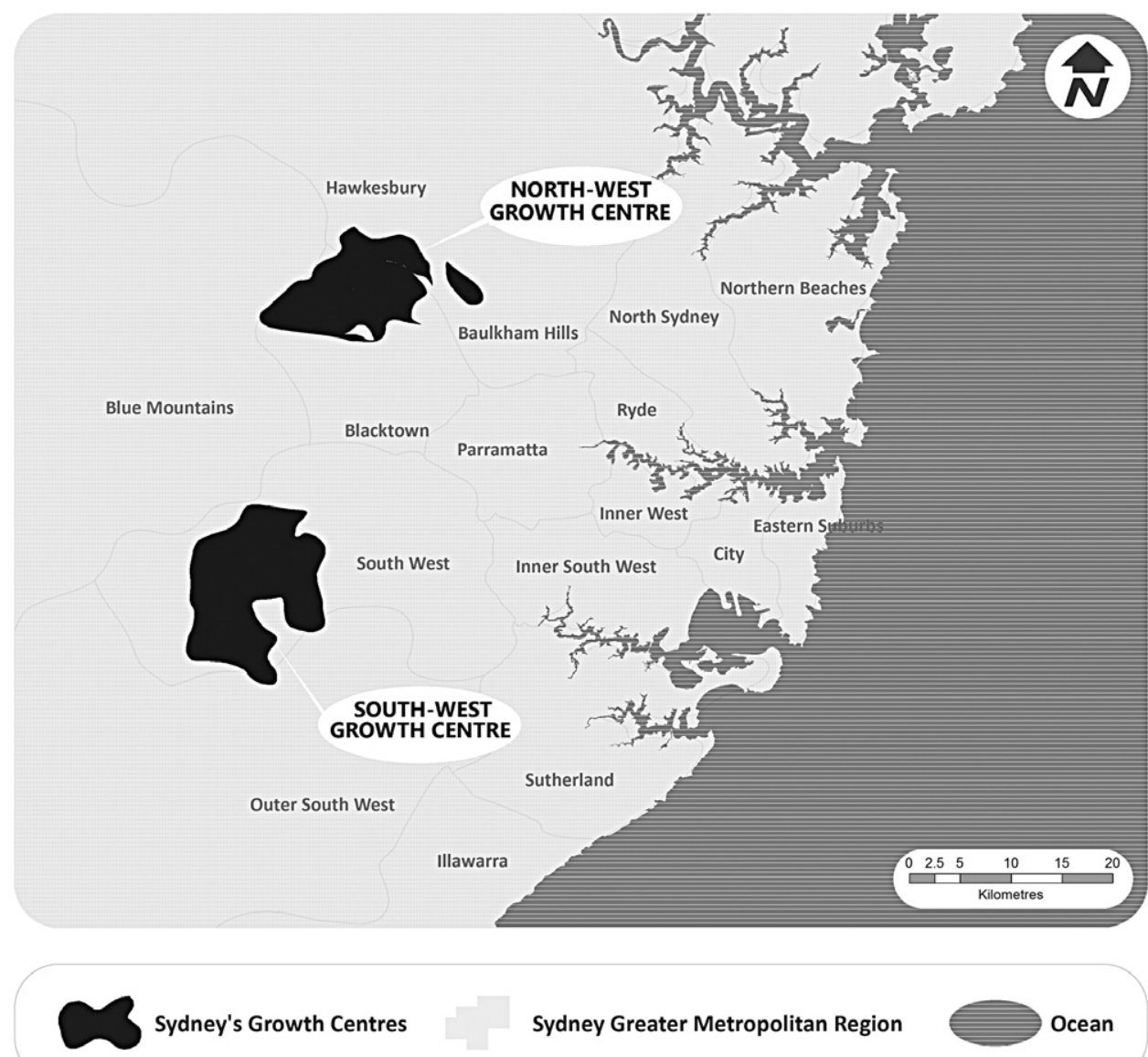

Sydney Greater Metropolitan Region

Ocean

Figure 1 Sydney's Growth Centres. Map supplied by Borce Dimeski. 
2007), and a number of rallies were staged, including one at Rossmore School in the South West Growth Centre that was attended by an estimated 300 people, as well as several in the city at Parliament House (Parliament of New South Wales, 2006). This landowner agitation led to the political abandonment of green zones with nothing to take their place.

Government representatives took the repeal of the green zones as evidence that the public, including landowners and farmers, did not want the conservation of farmland as part of Sydney's planned growth. More specifically, the protests about the green zones were also taken as a statement from the public about protecting farmland on Sydney's fringe. As a representative of the Growth Centres Commission asserted, 'One might argue that the original green zone allowed for [urban agriculture], [but] the community said its piece and said "We don't want that" ' (Growth Centres representative 2, pers. comm., 25 June 2007).

\section{An unwanted policy or poorly executed process?}

This declaration by a government representative represents a rather strained assessment of the residents' generally negative response to the plan for the green zones. The level of protest indicated that landowners overwhelmingly rejected the green zones policy as presented to them not because they rejected farmland protection but because they wished to have the option to sell their land for development in the future. The conflation of this rejection of a particular policy with a rejection of the idea of protecting farmland is problematic, as is the assumption that these protests represent the views of the entire fringe community.

The following data from interviews of the culturally and linguistically diverse small-scale farmers affected indicate that the sweeping statement by the government official presented previously fails to capture the nuances of their positions or the underlying social and political struggles taking place. These interviews were conducted as part of a four-year research project into the effect of urban development on these culturally and linguistically diverse growers on Sydney's south-western fringe. The views of this highly pertinent section of the fringe community were largely ignored in this protest and neglected in the consultation process, as will be detailed below. The interview responses from farmers illustrate that understanding the nuanced posi- tions of farmers on urban development and farmland protection is critical to creating a farmland protection policy that they could accept, and that, as a result, could be successful.

A key finding of the interviews with growers was that, in contrast to the apparent assumption by government representatives that farmers shared the position of the majority of landowners, there was a range of views on selling their land to developers. It is also important at this point to note that there were many farmers in the affected areas who were leasers, not landowners. For those who leased farmland, the green zones were largely positive. However, as leasers they felt that their views were given little weight by planning officials. As one VietnameseAustralian leaser explained: 'The green zone is good for the farmer but not good for owners. And it is usually owners who are stronger, and have their voices heard' (Vietnamese-Australian farmer 1, pers. comm., 25 August 2006). As it was primarily the landowning farmers who were in a position to either accept or protest the green zones, this paper will focus on their responses.

Of the farmers who were landowners, some wished to sell for development and saw the land as their 'superannuation', similarly to the majority of landowners who protested the green zones. As one Lebanese-Australian farmer explained, the low returns from primary production meant that the potentially lucrative profit from selling their land to developers was incredibly tempting for some farmers:

If the price is right they prefer to sell, because they don't make that sort of money. This property is earning them say 80000 a year. It goes up and up. They don't make that in the greenhouses. If the property is worth 1.5 million and the developer offers them 3 million, they won't make that money in 10 years. No way. (Lebanese-Australian farmer 2, pers. comm., 7 November 2006)

For those farmers keen to sell, there was a sense that they had a right to sell their land for development, regardless of how it was zoned when they bought it. As one Maltese-Australian farmer stated, 'Their concern with residential development is whether they are going to be justly rewarded for their prized belonging. They want to get a reasonable return on their investment' (Maltese-Australian farmer 1, pers. comm., 24 October 2006).

The desire to sell to developers was not uniform, however, with many landowning 
farmers wanting their land to keep farming into the foreseeable future. For one VietnameseAustralian farmer the potential profit from land sales was not as important as her farming lifestyle. She was not interested in selling:

Even if they say 'I'll pay you two million for just one block.' Two million is a lot of money, but not everyone wants money. They want to continue living and doing the things that they love. I do love farming, I have to admit even though it doesn't bring the income, I do love farming. (Vietnamese-Australian farmer 2, pers. comm., 6 December 2006)

Despite these different positions, it is important to note that all of the farmers interviewed those keen to sell and retire and those wanting to keep farming - were in agreement that their land was their biggest financial asset. The potential to profit from the sale of their land at some point, even if it was to be after they retired from farming, was therefore still important to longterm financial security for many. Rather than simply rejecting the idea of preserving farmland due to financial concerns, however, many farmers argued that the problem was political, as defined by the somewhat flawed approach to policy development. Instead, seemingly breaking the housing/farming divide, they argued for alternative policy approaches such as an option that allowed them to receive compensation if their land was to remain rural and undeveloped:

What I would like to see [is] a fair way for people to be given options. [The process] should be fair, evaluate the thing - what's the value for farming? And somehow compensate [the farmer], or the others. Put in a special tax. Compensate to make it fair. If his land is going to be nice and my land is going to be better value because his land is going to be used for views for my land, then I should be contributing to that, or the people who are going to be living here should contribute to that. Not him be the guinea pig ... and have to pay the price for it. I think that's unfair. (Lebanese-Australian farmer 1, pers. comm., 21 July 2006)

This response highlights why the green zones were problematic from the perspective of opposing landowning farmers: they asked farmers to forfeit the potential to profit from selling their land for a supposed greater public good. As $\mathrm{Mr}$ Michael Richardson, Member for the Hills District, argued in state parliament, 'The bottom line is if there are areas that require protection we should all pay for them. We should not expect individual landowners to bear the cost' (Parliament of New South Wales, 2005). In the context of farming, the proposed green zone policy forced individual farmers to choose between continuing farming and being able to eventually sell their land for development. If they chose to stay and farm, they would effectively be paying for the public's green space and the preservation of farmland on the urban fringe through the loss of their potential future profits from development.

\section{Community consultation}

The farmers' dissatisfaction with the green zones can therefore largely be attributed to a failure by government planners to adequately consult them about the way in which farmland should be protected. This was the result of a predominantly top-down approach to policy development and implementation, with few 'on-ground' assessments or consultations prior to the release of the draft policy and designation of proposed zones. As the aforementioned Member of Parliament, Michael Richardson, argues in the quote below, this top-down approach to policy-making meant that the land designated for the zones did not necessary reflect the best farmland or conservation areas:

The draft maps the Government released were based on outdated aerial photographs. In most cases they did not even send in anyone on the ground. ... One property owner who barely has a tree on his two hectares of land was entirely in the green zone. Down the road, Frank and Mary Bonello's hydroponics lettuce farm, which I visited last week, had the boundary going right through the middle of a shade cloth. (Parliament of New South Wales, 2005)

While these were draft maps on which landowners theoretically had the opportunity to comment, even the process of making changes to these drafts led to confusion among landowners. According to one farmer the creation and circulation of different maps meant that it was not clear to owners whether they were in or out of the green zones:

The mapping they were showing all the land owners was a different mapping than she seen ... so one bodgy [map] and one good [map].

And the good one they brought up at the 
meeting. (Maltese-Australian farmer 3, pers. comm., 22 November 2006)

That some landowning farmers would still have the option to sell their land for development and others would not led many farmers to view the creation of the zones as unfair and largely arbitrary:

I don't even like my neighbour to be done wrongly, you understand. I mean I was in the good side [not in the green zone] and he was in the wrong side, my next-door neighbour. What's fair is fair and that's not fair. (Lebanese-Australian farmer 1, pers. comm., 21 July 2006)

While farmers in Australia do not have development 'rights' to their land, and it can be zoned in whichever way the government of the day decides (Karanja and Rama, 2011), this quote indicates that landowners, including farmers, felt they had not been fairly treated in the process of allocating green zones and therefore would not support them.

Furthermore, there was a view among some farmers that the changes that did occur were largely at the behest of larger landowners, which resulted in the planned green zones overwhelmingly encompassing the land of smaller owners, including many farmers. According to these farmers, such instances led them to believe that they were being given incorrect information as to the location of the green zones and that the bigger landholders had much more power and ability to sway the decision-making process in their favour.

Even for those farmers who knew about meetings with New South Wales Department of Planning representatives, the mixture of confusion and imposition that was exhibited in their overall top-down approach to policy-making created a sense of futility about commenting: '[While] there are opportunities where they can give their comments, there is not much use because it is in the plan already' (Chinese-Australian farmer 8 through interpreter, pers. comm., 5 December 2007). The most farmers could hope to achieve through participation in these meetings was amendments to the existing schemes. There were no opportunities to present alternative ideas or schemes for farmland preservation.

The culturally and linguistically diverse nature of Sydney's vegetable farmers created additional barriers to participation. For the ChineseAustralian farmer quoted above, the fact that English was his second language made him reluctant to attend and talk at public consultation meetings: 'He said that because his English isn't good and the people speak English he can't express himself' (Chinese-Australian farmer 8 through interpreter, pers. comm., 5 December 2007). This language barrier was compounded if they did not receive adequate information or if the information was not translated into their language. As the farmer went on to say, the result was that in such a consultation process 'the one that doesn't speak English is the one that will lose out most' (Vietnamese-Australian Farmer 2, pers. comm., 6 December 2006). Even farmers who were proficient in English, however, did not have a strong sense of their right to be heard and participate in government decision-making (see also Parker, 2004). The linguistic and cultural diversity of the small-scale farmers, the limited consultation and the top-down nature of policy development were, then, all influential in the fate of the green zones.

\section{Alternatives from the fringe}

Examining the green zones process through a political ecology lens highlights the importance of equity in and access to the policy-making process to ensure that all voices are heard, particularly those of the most affected but also most marginalised group - the small-scale farmers. As Hillier (2002) has argued, a top-down approach to urban planning, such as that which shaped the green zones, is not about facilitating participation in policy development and allowing for ideas to be challenged and changed. Rather, it is about obtaining acquiescence to an already determined set of processes. This research has illustrated that the development of a successful new farmland preservation policy would require the opposite approach, with greater and improved consultation and engagement at the community level, particularly with the culturally and linguistically diverse small-scale farmers. Recognition of the need to undertake consultation with all relevant stakeholders in planning exercises is nothing new, with directives on how such consultation should take place stemming back to at least the 1960s (Cason and Gelber, 2001; Fincher and Iveson, 2008). In more recent decades, particularly since the 1990s, there has been attention in planning literature and policy to the need to identify and assist minority groups to participate in planning governance (Sandercock, 2005; Wood and Landry, 2008). However, as the case of the green zones illustrates, practice often falls short of these ideals (Cameron and Grant-Smith, 
2005). Furthermore, as Thompson and Dunn argue, the act of consultation itself does not necessarily ensure that people have a substantive influence on the decision-making process (Thompson and Dunn, 2002, 275). In creating an alternative policy for farmland protection in Sydney, therefore, it is not only greater consultation that is required, but also that the views of the people whom agricultural policy is intended to protect, the farmers themselves, are incorporated into policy development.

Undertaking greater consultation with farmers would be necessary to design a preservation scheme in a way that addressed the economic impost on farmers of restricting development on their highly valuable peri-urban land. The farmers interviewed had a number of suggestions for alternative schemes that would share the cost of preservation more equally between government and farmer, arguing, 'If we want to keep the Sydney basin active for this type of business, the government can do many, many different things, you know to keep the farmer here' (LebaneseAustralian farmer 3, pers. comm., 15 November 2006).

One option presented by one LebaneseAustralian farmer was the leasing of government land for agriculture, so that farmers could continue farming close to the city:

If the government really want agriculture in this area, they can afford us a big land. The government have plenty land, not using it they can use it for agriculture, if they are pushing this area to be subdivided. (LebaneseAustralian farmer 3, pers. comm., 15 November 2006)

Another option put forward by another Lebanese-Australian farmer is the adoption of a system of compensation for the farmer who effectively gives up his option for development:

In some other parts of the world, like in America where they have the same problem, but they managed to keep the farmland in areas where they are protected like farming by giving incentives. Incentives to people to stay where they are. Like if this area is subdivided and they give farmers a choice to stay as farmers but they compensate them. Like the value of land as farming land is different [to land sold for development] and they gave them the difference. (Lebanese-Australian farmer 1, pers. comm., 21 July 2006)

In this discussion of compensating or swapping land, the Lebanese-Australian farmer ges- tures to the idea of tradable or purchasable development rights. This is a model of farmland preservation particularly prevalent in the USA, where it has been considered largely successful (Daniels and Moore, 2009). The adoption of such a model has also been suggested in recent years by other reports on the Sydney Basin and other peri-urban farm regions (Sinclair et al., 2004; Elton Consulting, 2009). There are a number of barriers to the use of transferable development rights in Australia, including the establishment of a system in which to create and trade development credits, which have been discussed elsewhere (Karanja and Rama, 2011). While the details of what such a scheme would entail and how it would be applied in the Australian context (including Sydney specifically) are beyond the scope of this paper, it is an idea that deserves further investigation in terms of retaining farmers in the Sydney Basin. From the view of the Lebanese-Australian farmer quoted above, the benefactors of such a scheme are not simply the farmers but the wider community, as it has the potential to keep fresh food production close to the city:

It would be good for everybody, because in the end the higher the cost for this produce [if people have to move out of the city] it's going to cost us a lot to produce these things the higher a community's going to pay, so it's community investment in a way. These things, if we do them right - the politicians or the planners - if they do things right then they are making good investment for the community. (Lebanese-Australian farmer 1, pers. comm., 21 July 2006)

\section{Conclusion}

As Swyngedouw and Heynen (2003) concluded over a decade ago, discourses around urban socio-environmental sustainability are fundamentally political discourses. This study has emphasised the need for minority groups directly affected by environmental decision-making, such as Sydney's culturally and linguistically diverse farmers, to have a greater voice in these discourses. If minority groups are able to influence how environmental problems, such as protecting urban farmland, are understood by governing bodies, they can, in turn, influence how this problem is addressed in the policy development process. In the case of Sydney, greater consultation with farmers would ensure that policymakers hear their views of the issue and their alternative solutions. 
Rather than persisting in creating policy that preserves farmland based on a housing-versusfarms dichotomy, the interview data from farmers suggests the need to achieve 'a happy functioning medium' (Maltese-Australian farmer 6, pers. comm., 2 February 2007). While achieving this medium initially appears deceptively simple - that is, in the words of a MalteseAustralian farmer, 'Just leave some agricultural land and don't put houses on everything' (Maltese-Australian Farmer 6, pers. comm., 2 February 2007) - the question raised by the failure of Sydney's green zones is not simply that of a choice between farms and housing. Adopting an urban political ecology lens shows it is possible that the green zone failure was a result of a particular policy development process, rather than an inevitable consequence of incompatible land uses. The issue of 'who' participates in such environmental decision-making has repercussions in terms of determining what kind of urban growth is planned for, how it is implemented and whether it generates equitable and sustainable outcomes. This finding reinforces Sandercock and Kliger's (1998) conclusion over a decade ago that planning for diversity requires a more participatory democracy. The reticence to adopt what are now well-established practices to facilitate greater consultation with diverse groups can arguably still be attributed to the factors she identified: that political expediency often trumps the ideals of participation, which imposes additional costs of time and money.

If, as many commentators suggest, retaining farmland on the urban fringe is of value to the city community, this study illustrates that it cannot be done through a top-down 'take it or leave it' approach to policy-making. The multiple priorities of farmers, including protecting their perceived investment through the option to sell for housing development, must be addressed to ensure that farmland protection policies are viable for the very section of the community they are intended to protect. Sydney's failed green zones serve to illustrate how agricultural land may be preserved if appropriate bottom-up approaches to consultation and engagement that take into account the needs of linguistically and culturally diverse farmers are implemented from the outset.

In recognizing the political nature of sustainability initiatives such as farmland protection, this case study supports the urban political ecology assertion that socio-ecological processes within cities are not apolitical. Rather they are often shaped by power struggles of race and class. Building on these findings, my research suggests that uncovering these power struggles creates the opportunity for alternative, and more successful, approaches to urban sustainability initiatives such as farmland protection. In the case of Sydney, rather than assuming that farming will inevitably be lost to housing development, a more inclusive approach to policy development could allow for farming to continue on the urban fringe.

\section{ACKNOWLEDGEMENTS}

I would like to thank my thesis supervisors, Kay Anderson, Ien Ang and Fiona Allon, for all their assistance with the research on which this paper is based. I would also like to thank Borce Dimeski for the production of the map, Adam Trau for his comments on earlier drafts of this paper, the editors and Special Issue editors of Geographical Research for their assistance, and the two anonymous reviewers for their constructive comments that have strengthened the paper.

\section{REFERENCES}

Ali, A.K., 2008: Greenbelts to contain urban growth in Ontario, Canada: promises and prospects. Planning Practice and Research 23, 533-548.

Amati, M. (ed.), 2008: Urban Green Belts in the 21st Century. Ashgate, Hampshire.

Anderson, K., 2005: Introduction: after sprawl: postsuburban Sydney. In Anderson, K., Dobson, R., Allon, F. and Neilson, B. (eds) Post-Suburban Sydney: The City in Transformation. University of Western Sydney, Sydney, $3-11$.

Bunker, R. and Houston, P., 2003: Prospects for the ruralurban fringe in Australia: observations from a brief history of the landscapes around Sydney and Adelaide. Australian Geographical Studies 41, 303-323.

Cameron, J. and Grant-Smith, D., 2005: Building citizens: participatory planning practice and a transformative politics of difference. Urban Policy and Research 23, 21-36.

Cason, L. and Gelber, K., 2001: Ideas for Community Consultation: A Discussion on Principles and Procedures for Making Consultation Work. NSW Department of Urban Affairs and Planning, Sydney.

Daniels, T. and Moore, C., 2009: Saving farms and farmland. Planning 75, 38-43.

Dixon, J., Omwega, A., Friel, S., Burns, C., Donati, K. and Carlisle, R., 2007: The health equity dimensions of urban food systems. Journal of Urban Health 84, 118-129.

Elton Consulting, 2009: Sydney's Agriculture - Planning for the Future (Forums Outcomes Report). New South Wales Department of Primary Industries, Sydney.

Fincher, R. and Iveson, K., 2008: Planning and Diversity in the City: Redistribution, Recognition and Encounter. Palgrave Macmillan, New York.

Freestone, R., 1992: Sydney's green belt 1945-1960. Australian Planner 30, 70-77.

Hillier, J., 2002: Shadows of Power: An Allegory of Prudence in Land-Use Planning. Routledge, London and New York.

James, S., O'Neill, P., Domeski, B. and Crabtree, L., 2010: Sydney's Agricultural Lands: An Analysis. Urban Research Centre, University of Western Sydney for NSW Department of Planning, Sydney. 
Karanja, F. and Rama, I., 2011: Land use planning challenges and tools - tradeable development rights: design considerations. Presented at Australian Agricultural and Resource Economics 2011 conference, 8-11 February 2011, Melbourne.

Land and Water Australia, 2008: Change and Continuity in Peri-Urban Australia. Land and Water Australia, Canberra.

Low Choy, D., Sutherland, C., Gleeson, B., Snipe, N. and Dodson, J., 2008: Change and Continuity in Peri-Urban Australia: Peri-Urban Futures and Sustainable Development. Griffith University, Brisbane.

Malcolm, P. and Fahd, R., 2009: Ground Truthing of the Sydney Vegetable Industry in 2008. Horticulture Australia Limited, NSW Department of Primary Industries, Sydney.

McNeill, D., Dowling, R. and Fagan, B., 2005: Sydney/ global/city: an exploration. International Journal of Urban and Regional Research 29, 935-944.

Mougeot, L.J.A., 2005: Agropolis: The Social, Political and Environmental Dimensions of Urban Agriculture. Earthscan, London.

New South Wales Department of Planning, 2005a: Growth Centres: your questions answered. Retrieved: 1 August 2006 from <http://www.metrostrategy.nsw.gov.au/dev/ ViewPage. action?siteNodeId=59\&languageId=1 \&contentId $=407 \% 3 \mathrm{E}>$.

New South Wales Department of Planning, 2005b: City of Cities: A Plan for Sydney's Future. New South Wales Government, Sydney.

New South Wales Department of Planning, 2010: Sydney Towards 2036: A Discussion Paper. NSW Government, Sydney.

Parker, F., 2004: Farming Women of Non-English Speaking Background: Developing Innovative Access Strategies through Partnerships. New South Wales Department of Women, Sydney.

Parliament of New South Wales, 2005: North-West and South-West Sydney land rezoning. Legislative Council
(Hansard). Retrieved: 21 August 2007 from <http:// www.parliament.nsw.gov.au/prod/parlment/HansArt.nsf/ V3Key/LC20050913099\%3E >.

Parliament of New South Wales, 2006: South-Western Sydney land rezoning. Legislative Council (Hansard). Retrieved: 2 February 2007 from <http://www.parliament. nsw.gov.au/prod/parlment/hansart.nsf/5f584b237987507a ca256d09008051f3/9302593ce1e9c221ca257135007933 ec!OpenDocument\%3E>.

Sandercock, L., 2005: Mongrel cities: a 21st century urban reality. Soziale Welt 56, SPEC. ISS., 347-361.

Sandercock, L. and Kliger, B., 1998: Multiculturalism and the planning system: part two. Australian Planner 35, 223 227.

Sinclair, I., Docking, A., Jarecki, S., Parker, F. and Saville, L., 2004: From the Outside Looking In: The Future of Sydney's Rural Land: Background Issues and Workshop Outcomes. University of Western Sydney, Sydney.

Spearritt, P. and Demarco, C., 1988: Planning Sydney's Future. Allen and Unwin in conjunction with the New South Wales Department of Planning, Sydney.

State Planning Authority of New South Wales, 1967: Sydney Region: Growth and Change. New South Wales Government, Sydney.

Swyngedouw, E. and Heynen, N.C., 2003: Urban political ecology, justice and the politics of scale. Antipode 35, 898-918.

Thompson, S. and Dunn, K., 2002: Multicultural services in local government in Australia: an uneven tale of access and equity. Urban Policy and Research 20, 263-279.

Winston, D., 1957: Sydney's Great Experiment: The Progress of the Cumberland County Plan. Angus and Robertson, Sydney.

Wood, P. and Landry, C., 2008: The Intercultural City: Planning for Diversity Advantage. Earthscan, London. 